\title{
BERKOMUNIKASI DENGAN BERBAHASA YANG EFEKTIF DAPAT MENINGKATKAN KINERJA
}

\author{
Waridah \\ Universitas Medan Area \\ henikhairina@gmail.com
}

\begin{abstract}
Abstrak
Bahasa dan komunikasi memiliki hubungan yang sangat erat dan. Hubungan keduanya tercermin dalam pengertian bahasa menurut rumusan linguistik dan tinjauan komunikasi, yaitu bahasa sebagai alat atau media komunikasi yang digunakan oleh manusia dalam berinteraksi dengan sesamanya. Sebaliknya komunikasi, membutuhkan media yaitu bahasa. Komunikasi terbagi dua yaitu komunikasi verbal dan nonverbal. Komunikasi verbal adalah bentuk yang disampaikan komunikator kepada komunikan dengan cara tertulis atau lisan. Komunikasi nonverbal menempati porsi penting. Banyak komunikasi verbal tidak efektif hanya karena komunikatornya tidak menggunakan komunikasi nonverbal dengan baik dalam waktu bersamaan. Dalam menjalankan aktivitas sehari-hari, setiap organisasi cenderung merupakan kesatuan yang kompleks, yang berusaha mengalokasikan sumber dayanya secara rasional demi tercapainya tujuan. Walaupun rasionalisasi yang sempurna jarang tercapai, usaha mencapainya tetap merupakan ciri manajemen modern. Manajemen yang baik adalah manajemen yang dapat memanfaatkan sumber daya yang tersedia dengan tujuan untuk mencapai dan memelihara tingkat operasi yang efektif. Penyusunan struktur organisasi yang sesuai dengan perkembangan dan kebutuhan perusahaan akan menciptakan kesesuaian kerja, pendelegasian wewenang dan tanggung jawab serta komunikasi yang baik, dapat mempertinggi tingkat efisiensi.
\end{abstract}

Kata kunci: efisien, efektif, kinerja

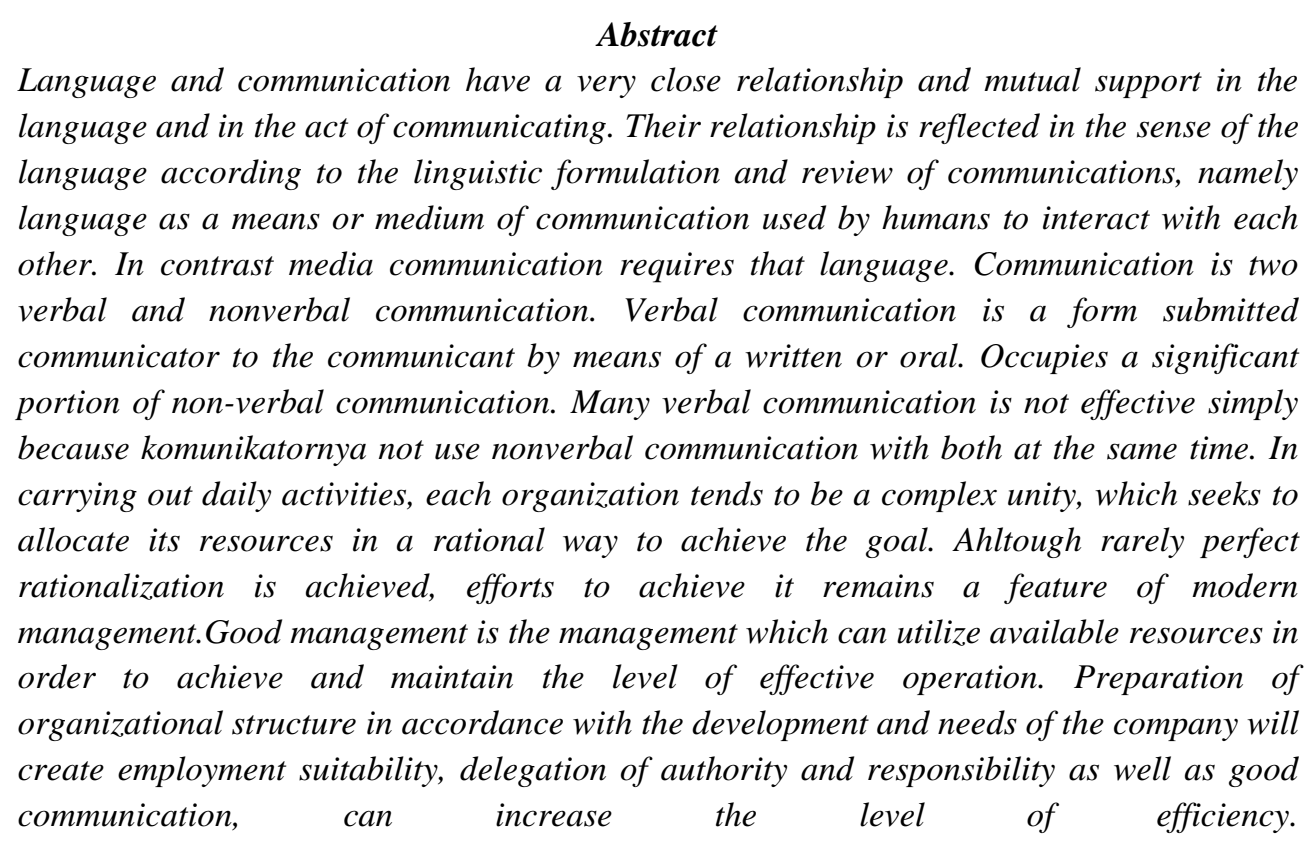

Keywords: efficient, effective, performance 


\section{PENDAHULUAN}

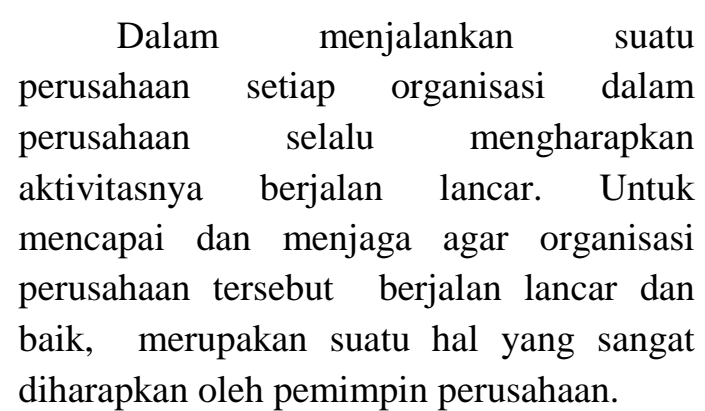

Dalam hal ini diperlukan alat pengikat yang jelas dari hubunganhubungan/ hirarki dalam organisasi yaitu informasi dan komunikasi. Karena itu, semua organisasi, baik dalam bentuk apapun dan apa tujuannya harus dibantu, disatukan dalam melakukan fungsinya melalui proses komunikasi. Komunikasi dan informasi melalui bahasa yang baik dan benar dalam satu organisasi perusahaanadalah satu proses di mana dua orang atau lebih membentuk atau melakukan pertukaran informasi dengan satu sama lainnya yang pada gilirannya akan tiba pada saling pengertian yang mendalam.

Komunikasi dengan bahasa yang baik dan benar termasuk hal yang paling wajar dalam pola tindakan manusia untuk menjalankan perusahaan, tetapi meskipun begitu juga yang paling kompleks dan rumit. Tidaklah mungkin membayangkan manusia pada komunikasi. Komunikasi antar manusia sudah mulai berlangsung semenjak lahir, dan dilakukan hampir sewajar dan leluasa tindakan bernafas. Baru kemudian, apabila kita harus membujuk atau mendesak orang lain, menulis karangan, membuat film atau mengajarkan keterampilan yang rumit, kita sadar bahwa komunikasi dan berbahasa sebenarnya merupakan suatu hal yang sukar dan berbelit-belit.

Komunikasi dengan bahasa yang baik dan benar adalah komunikasi dua arah, akan tetapi dalam organisasi sering terjadi komunikasi tidak langsung, misalkan suatu perintah menurut prinsip organisasi harus mengalir dari atas ke bawah melalui rantairantai komando. Demikian juga pertanggungjawaban dari bawah akan naik melalui jenjang komando dan hirarki, sehingga dengan demikian prinsip akan mempengaruhi kecepatan dan ketepatan berkomunikasi. Sedangkan berkomunikasi satu arah sering mengalami kesukaran, karena komunikasinya harus disusun dan direncanakan dengan bahasa yang baik dan benar menurut kaidah bahasa sedemikian rupa, agar penerima cukup jelas.

Bahasa sebagai alat komunikasi antara anggota masyarakat berupa simbol bunyi yang dihasilkan oleh alat ucap manusia. Bahasa adalah sistem komunikasi yang mempergunakan simbol-simbol vokal (bunyi ujaran) yang bersifat arbitrer. Dari kedua pengertian tersebut di atas bila dikaitkan dengan pengertian komunikasi, maka bisa didapatkan bahwa keduanya memiliki hubungan yang erat antara satu dengan yang lainnya. Bahasa merupakan alat untuk terciptanya sebuah komunikasi yang baik. Begitu pula komunikasi, bahasa merupakan satu hal yang primer untuk mencapai komunikasi yang baik.

Komunikasi adalah alat dengan mana hubungan kemanusiaan berlangsung, ia adalah arus yang telah mengalir sepanjang sejarah manusia, yang selalu memperluas wawasan seseorang dengan jalur-jalur informasinya. Komunikasi adalah keterampilan manusia dalam berbahasa yang paling luar biasa. Komunikasi adalah suatu proses dengan mana informasi antar individual ditukarkan melalui simbol, tanda, atau tingkah laku yang umum.Dari definisi komunikasi di atas bahwa komunikasi sebagai satu proses melibatkan (1) pihak yang berkomunikasi, (2) informasi yang dikomunikasikan, (3) alat komunikasi. Tidak ada komunikasi yang tidak melibatkan ketiga aspek di atas dan 
sesungguhnya manusia itu tidak akan terlepas dari ketiga aspek tersebut.

Berkomunikasi yang baik adalah suatu proses dalam mana seseorang atau beberapa orang, kelompok, organisasi, dan masyarakat menciptakan, dan menggunakan informasi agar terhubung dengan lingkungan dan orang lain. Saat ini, di mana kita telah melakukan komunikasi lewat satelit, dengan mudah kita telah dapat mengamati makhluk-makhluk di bagian lain bumi, berbicara dan membicarakan mereka. Di kala sendiri pun manusia dapat juga berkomunikasi paling tidak kepada dirinya sendiri, atau dengan alam lingkungannya. Semua tingkah laku manusia pada ukuran tertentu bersifat komunikatif dalam pengertian bahwa seseorang pengamat dengan memperhatikan tingkah laku seseorang akan mendapatkan sesuatu (informasi), kendatipun seseorang itu tidak menyadari atau tidak bermaksud berkomunikasi dengan si pengamat tadi.

Proses komunikasi adalah bagaimana komunikator menyampaikan pesan kepada komunikannya, sehingga dapat menciptakan suatu persamaan makna antara komunikan dengan komunikatornya. Proses komunikasi ini bertujuan untuk menciptakan komunikasi yang efektif. Proses komunikasi termasuk juga suatu proses penyampaian informasi dari satu pihak ke pihak laindi mana seseorang atau beberapa orang, kelompok, organisasi dan masyarakat menciptakan dan menggunakan informasi agar terhubung dengan lingkungan orang lain.

$$
\text { Pada umumnya komunikasi }
$$

dilakukan secara lisan atau verbal yang dapat dimengerti oleh kedua belah pihak. Apabila tidak ada bahasa verbal yang dapat dimengerti oleh keduanya, komunikasi masih dapat dilakukan dengan menggunakan gerak- gerik badan, dan menunjukkan sikap tertentu seperti tersenyum, mengangkat bahu dan sebagainya. Komunikasi ini disebut komunikasi nonverbal. Proses komunikasi bertujuan untuk menciptakan komunikasi yang efektif. Proses komunikasi dapat terjadi apabila ada interaksi antar manusia dan ada penyampaian pesan untuk mewujudkan motif komunikasi. Melalui komunikasi sikap dan perasaan seseorang atau sekelompok orang dapat dipahami oleh pihak lain.

\section{PEMBAHASAN}

Proses komunikasi ada enam tahap; yaitu:

1. Pengirim mempunyai suatu ide atau gagasan

Sebelum proses penyampaian pesan dapat dilakukan, maka pengirim pesan harus menyiapkan ide atau gagasan apa yang ingin disampaikan kepada pihak lain atau audiens. Ide dapat diperoleh dari berbagai sumber yang terbentang luas di hadapan kita. Dunia ini penuh dengan berbagai macam informasi, baik yang dapat dilihat, didengar, dicium maupun diraba. Ide-ide yang ada dalam benak kita disaring dan disusun ke dalam suatu memori yang ada dalam jaringan otak, yang merupakan gambaran persepsi kita terhadap kenyataan. Setiap orang akan memiliki peta mental yang berbeda, karena kita memandang dunia dan menyerap berbagai pengalaman dengan suatu cara yang unik dan bersifat individual.

Karena persepsi adalah hal yang unik, ide yang disampaikan seseorang mungkin akan ditafsirkan secara berbeda oleh orang lain. Bahkan dua orang yang memiliki suatu pengalaman yang sama terhadap sesuatu hal atau kejadian, akan memiliki suatu kesan yang tidak serupa. Sebagai contoh ada dua orang yang bersama-sama mengikuti briefing dari pimpinan perusahaan. Apabila mereka diminta untuk menceritakan pengalaman mereka masing-masing, tentu ada beberapa hal yang berbeda. 
2. Pengirim mengubah ide menjadi suatu pesan

Dalam suatu proses komunikasi, tidak semua ide dapat diterima atau dimengerti dengan sempurna. Proses komunikasi dimulai dengan adanya ide dalam pikiran, yang lalu diubah ke dalam bentuk pesanpesan seperti dalam bentuk kata-kata, ekspresi wajah, dan sejenisnya untuk kemudian dipindahkan kepada orang lain.

Agar ide dapat diterima dan dimengerti secara sempurna, pengirim pesan harus memperhatikan beberapa hal, yaitu subjek (apa yang ingin disampaikan), maksud, audiens, gaya personal, dan latar belakang budaya. Sebagai contoh sederhana, pada umumnya orang Timur cenderung menyampaikan pesan dengan menggunakan bahasa tak langsung dan bahasa penghalus. Untuk menyatakan sikap menolak, seseorang terlebih dahulu harus menggunakan kalimat-kalimat pembuka yang bersifat netral, baru kemudian menyatakan sikap penolakan.

\section{Pengirim menyampaikan pesan}

Setelah mengubah ide-ide ke dalam suatu pesan, tahap berikutnya adalah memindahkan atau menyampaikan pesan melalui berbagai saluran yang ada kepada si penerima pesan. Rantai saluran komunikasi yang digunakan untuk menyampaikan pesan terkadang relatif pendek, namun ada juga yang cukup panjang. Panjang pendeknya rantai saluran komunikasi yang digunakan akan berpengaruh terhadap efektivitas penyampaian pesan. Bila pesan yang panjang dan kompleks disampaikan secara lisan, pesan-pesan tersebut bisa terdistorsi atau bahkan bertentangan dengan pesan aslinya. Di samping itu, dalam menyampaikan suatu pesan, berbagai media komunikasi dapat digunakan, media tulisan maupun lisan. Oleh karena itu, perlu diperhatikan jenis atau sifat pesan yang akan disampaikan.

\section{Penerima menerima pesan}

Komunikasi antara seseorang dengan orang lain akan terjadi, bila pengirim mengirimkan suatu pesan dan penerima menerima pesan tersebut. Jika seseorang mengirim sepucuk surat, komunikasi baru bisa terjalin bila penerima surat telah membaca dan memahami isinya. Jika seseorang menyampaikan pidato dengan bahasa yang baik dan benar di hadapan umum, para pendengar sebagai audiens harus dapat mendengar apa yang dikatakan, dan memahami pesan-pesan yang disampaikan.

\section{Penerima menafsirkan pesan}

Setelah penerima menerima suatu pesan, tahap berikutnya adalah bagaimana ia dapat menafsirkan pesan. Suatu pesan yang disampaikan pengirim harus mudah dimengerti dan tersimpan di dalam benak pikiran si penerima pesan. Selanjutnya suatu pesan baru dapat ditafsirkan secara benar bila penerima pesan telah memahami isi pesan sebagaimana yang dimaksud oleh pengirim pesan.

6. Penerima memberi tanggapan dan mengirim umpan balik kepada pengirim Umpan balik (feedback) adalah penghubung akhir dalam suatu mata rantai komunikasi. Ia merupakan tanggapan penerima pesan yang memungkinkan pengirim untuk menilai efektivitas suatu pesan.

Setelah menerima pesan, penerima akan memberi tanggapan dengan cara tertentu dan memberi sinyal terhadap pengirim pesan. Sinyal yang diberikan oleh penerima pesan beraneka macam, dapat berupa suatu senyuman, tertawa, sikap murung, cemberut, memberi komentar sekilas (singkat), anggukan sebagai pembenaran, atau pesan secara tertulis. Sebagai contoh, seorang karyawan perusahaan menerima sepucuk surat dari 
pimpinannya. Sesaat kemudian surat tersebut dibacanya. Apabila ekspresi wajahnya Nampak murung, berarti dapat diduga bahwa ia menerima berita yang kurang menyenangkan. Sebaliknya jika ia menerima surat dari pimpinannya dan setelah dibacanya Nampak ekspresi wajah yang berseri-seri dapat diduga bahwa ia menerima berita yang menyenangkan. Bentuk ekspresi wajah tersebut adalah contoh umpan balik dalam berkomunikasi. Umpan balik memegang peranan penting dalam proses komunikasi, karena ia memberi kemungkinan bagi pengirim untuk menilai efektivitas suatu pesan. Di samping itu, adanya umpan balik dapat menunjukkan adanya faktor-faktor penghambat komunikasi, misalnya perbedaan latar belakang, perbedaan penafsiran kata-kata, dan perbedaan reaksi secara emosional.

\section{Fungsi Komunikasi}

Fungsi komunikasi dalam organisasi sangat besar. Organisasi yang berorientasi untuk mencari keuntungan (profit) maupun nirlaba (non-profit), dapat diuraikan sbb:

a. Sebagai kendali. Fungsi komunikasi sebagai kendali memiliki arti bahwa komunikasi bertindak untuk mengendalikan prilaku orang lain atau anggota dalam beberapa cara yang harus dipatuhi.

b. Sebagai motivasi. Komunikasi memberikan perkembangan dalam memotivasi dengan memberikan penjelasan dalam hal-hal dalam kehidupan kita.

c. Sebagai pengungkapan emosional. Komunikasi memiliki peranan dalam mengungkapkan perasaan-perasaan kepada orang lain, baik itu senang, gembira, kecewa, tidak suka, dan lainnya.

d. Sebagai informasi. Komunikasi memberikan informasi yang diperlukan dari setiap individu dan kelompok dalam mengambil keputusan dengan meneruskan data guna mengenai dan menilai pemilihan alternatif.

\section{Gangguan dan Rintangan Komunikasi}

Jika kita melihat hakikat komunikasi sebagai suatu sistem, maka gangguan komunikasi bisa terjadi pada semua elemen atau unsur-unsur yang mendukungnya, termasuk faktor lingkungan di mana komunikasi itu terjadi. Menurut Shannon dan Weaver (dalam Hafied Cangara) gangguan komunikasi terjadi jika terdapat intervensi yang mengganggu salah satu elemen komunikasi, sehingga proses komunikasi tidak dapat berlangsung secara efektif. Sedangkan rintangan komunikasi dimaksudkan ialah adanya habatan yang membuat proses komunikasi tidak dapat berlangsung sebagaimana harapan komunikator dan penerima.

Meski gangguan dan rintangan komunikasi dapat dibedakan, tetapi sebenarnya rintangan komunikasi bisa juga terjadi disebabkan karena adanya gangguan. Gangguan dan rintangan komunikasi pada dasarnya dapat dibedakan atas tujuh macam, yakni:

a. Gangguan teknis

Gangguan teknis terjadi jika salah satu alat yang digunakan dalam berkomunikasi yang ditransmisi melalui saluran mengalami kerusakan (channel noise). Misalnya gangguan pada stasiun radio dan televisi, gangguan jaringan telepon, rusaknya pesawat radio sehingga terjadi suara bising dan semacamnya.

b. Gangguan semantik

Gangguan semantik adalah gangguan komunikasi yang disebabkan karena kesalahan pada bahasa yang digunakan (Blake dalam Hafied Cangara). Gangguan semantik sering terjadi karena:

- Kata-kata yang digunakan terlalu banyak memakai jargon bahasa asing 
sehingga sulit dimengerti oleh khalayak tertentu

- Bahasa yang digunakan pembicara berbeda dengan bahasa yang digunakan oleh penerima

- Struktur bahasa yang digunakan tidak sebagaimana mestinya, sehingga membingungkan penerima

- Latar belakang budaya yang menyebabkan salah persepsi terhadap simbol-simbol bahasa yang digunakan.

c. Gangguan psikologis

Gangguan psikologis terjadi karena adanya gangguan yang disebabkan oleh persoalan-persoalan dalam diri individu. Misalnya rasa curiga penerima kepada sumber, situasi berduka atau karena gangguan kejiwaan sehingga dalam penerimaan dan pemberian informasi tidak sempurna.

d. Rintangan fisik atau organik

Rintangan fisik ialah rintangan yang disebabkan karena kondisi geografis misalnya jarak yang jauh sehingga sulit dicapai, tidak adanya sarana kantor pos, kantor telepon, jalur transportasi dan semacamnya. Dalam komunikasi antarmanusia, rintangan fisik bisa juga diartikan karena adanya gangguan organik, yakni tidak berfungsinya salah satu pancaindra pada penerima.

e. Rintangan status

Rintangan status ialah rintangan yang disebabkan karena jarak sosial di antara peserta komunikasi, misalnya perbedaan status antara senior dan junior atau atasan dan bawahan. Perbedaan seperti ini biasanya menuntut prilaku komunikasi yang selalu memperhitungkan kondisi dan etika yang sudah membudaya dalam masyarakat, yakni bawahan cenderung hormat pada atasannya, atau rakyat pada raja yang memimpinnya.

f. Rintangan kerangka berpikir

Rintangan kerangka berpikir ialah rintangan yang disebabkan adanya perbedaan persepsi antara komunikator dan khalayak terhadap pesan yang digunakan dalam berkomunikasi. Ini disebabkan karena latar belakang pengalaman dan pendidikan yang berbeda.

Rintangan budaya

Rintangan budaya ialah rintangan yang terjadi disebabkan karena adanya perbedaan norma, kebiasaan dan nilai-nilai yang dianut oleh pihak-pihak yang terlibat dalam komunikasi.

\section{Jenis Komunikasi}

Pada dasarnya ada dua bentuk dasar komunikasi yang lazim digunakan dalam dunia bisnis, yaitu komunikasi verbal dan komunikasi nonverbal.

Komunikasi verbal (verbal communication) dalam pemakaiannya menggunakan bahasa, sedangkan komunikasi nonverbal menggunakan isyarat dalam berkomunikasi. Bahasa dapat didefinisikan seperangkat kata yang telah disusun secara berstruktur sehingga menjadi himpunan kalimat yang mengandung arti.

Bahasa memiliki banyak fungsi, namun sekurang-kurangnya ada tiga fungsi yang erat hubungannya dalam menciptakan komunikasi yang efektif, yakni:

- untuk mempelajari tentang dunia sekeliling kita

- untuk membina hubungan yang baik di antara sesama manusia

- untuk menciptakan ikatan-ikatan dalam kehidupan manusia.

Untuk mempelajari dunia sekeliling kita, bahasa menjadi peralatan yang sangat penting dalam memahami lingkungan. Melalui bahasa, kita dapat mengetahui sikap, perilaku dan pandangan suatu bangsa, meski kita belum pernah berkunjung ke negaranya. Pendek kata bahasa memegang peranan penting bukan saja dalam hubungan antarmanusia, tetapi juga dalam pengembangan ilmu 
pengetahuan dan pewarisan nilai-nilai budaya dari generasi pendahulu kepada generasi pelanjut. Bahasa mengembangkan pengetahuan kita, agar kita dapat menerima sesuatu dari luar dan juga berusaha untuk menggambarkan ide-ide kita kepada orang lain.

Begitu pentingnya peranan bahasa dalam pengembangan ilmu pengetahuan, sebuah pengadilan di Inggris pada tahun 1970 menjatuhkan hukuman penjara kepada seorang ibu karena lalai mengajarkan anaknya untuk bisa berbahasa (Abraham dalam Hafied Cangara). Rasanya sulit dibayangkan berapa banyak ilmu pengetahuan yang hilang bagi orang yang tidak bisa menggunakan bahasa verbal. Dengan demikian dapat dikatakan manusia dalam meningkatkan kemampuannya untuk berbahasa perlu melalui proses belajar.

Tanpa bahasa manusia tidak bisa berpikir, bahasalah yang mempengaruhi persepsi dan pola-pola berpikir seseorang.

Dalam dunia bisnis, seseorang dapat saja mengekspresikan pesan-pesannya secara nonverbalartinya berkomunikasi tanpa mengeluarkan kata-kata dengan menggunakan bahasa isyarat atau bahasa diam (silent language).

Mark Knapp dalam Hafied Cangara mengatakan penggunaan nonverbal dalam berkomunikasi memiliki fungsi untuk:

- meyakinkan apa yang diucapkannya (repetition)

- menunjukkan perasaan dan emosi yang tidak bisa diutarakan dengan kata-kata (substitution)

- menunjukkan jati diri sehingga orang lain bisa mengenalnya (identity)

- menambah atau melengkapi ucapanucapan yang dirasakan belum sempurna.

Pemberian arti terhadap bahasa nonverbal sangat dipengaruhi oleh sistem sosial budaya masyarakat yang menggunakannya. Misalnya meludah di depan orang dipandang oleh beberapa kelompok masyarakat di Asia sebagai perbuatan yang kurang terpuji.

Komunikasi nonverbal dapat dikelompokkan dalam beberapa bentuk, yaitu: dengan gerakan badan, ekspresi wajah (tertawa, menangis, tersenyum, sinis), mengangguk atau menggelengkan kepala, menggerutu, mengepal tinju ke atas meja, tolak pinggang, gerakan mata (kontak mata), sentuhan badan, diam, dll.

Bahasa lisan adalah bahasa yang dihasilkan alat ucap (organ of speech) dengan fonem sebagai unsur dasar. Dengan bahasa lisan kita berurusan dengan tatabahasa, kosakata, dan lafal. Dalam ragam bahasa lisan ini, pembicara dapat memanfaatkan tinggi rendahnya suara atau tekanan, air muka, gerak tangan atau isyarat untuk mengungkapkan ide.

Contoh:

Ibu bilang kita harus kuliah.

Ayah lagi baca majalah.

Saya tinggal di Medan.

Bahasa tulisan adalah bahasa yang dihasilkan dengan memanfaatkan tulisan dengan huruf sebagai unsur dasarnya. Dalam ragam tulis, kita berurusan dengan tatacara penulisan (ejaan) di samping aspek tatabahasa dan kosakata. Dengan kata lain dalam ragam bahasa tulis, kata dituntut adanya kelengkapan unsur tatabahasa seperti bentuk kata ataupun susunan kalimat, ketepatan pilihan kata, kebenaran penggunaan ejaan, dan penggunaan tanda baca dalam pengungkapan.

Contoh:

Ibu mengatakan kita harus kuliah. Ayah sedang membaca majalah.

Saya bertempat tinggal di Medan.

\section{Tujuan Berkomunikasi}

Seseorang berkomunikasi dengan orang lain tentu saja mempunyai tujuan tertentu, 
ada beberapa tujuan yang ingin dicapai dalam komunikasi, yaitu:

a. Supaya yang disampaikan komunikator dapat dimengerti oleh komunikan. Agar dapat dimengerti oleh komunikan maka komunikator perlu menjelaskan pesan utama dengan sejelas-jelasnya dan sedetail mungkin.

b. Agar dapat memahami orang lain. Dengan melakukan komunikasi, setiap individu dapat memahami individu yang lain dengan kemampuan mendengar apa yang dibicarakan orang lain

c. Agar pendapat kita diterima orang lain. Komunikasi dan pendekatan persuasif merupakan cara agar gagasan kita diterima oleh orang lain

d. Menggerakkan orang lain untuk melakukan sesuatu. Komunikasi dan pendekatan persuasif kita mampu membangun persamaan persepsi dengan orang, kemudian menggerakkannya sesuai dengan keinginan kita.

\section{Hubungan Komunikasi dengan Efisiensi dan Efektivitas Kinerja}

Penyelesaian yang efektif atau memilih tujuan-tujuan yang tepat dari serangkaian alternatif belum tentu efisien begitu juga sebaliknya yang efektif bisa saja membutuhkan sumber daya yang sangat besar sedangkan yang efisien barangkali memakan waktu yang lama. Sehingga sebisa mungkin efektivitas dan efisiensi bisa mencapai tingkat optimum untuk kedua-duanya.

Efektivitas merupakan pencapaian tujuan secara tepat atau memilih tujuantujuan yang tepat dari serangkaian alternatif atau pilihan cara dan menentukan pilihan dari beberapa pilihan lainnya. Efektivitas bisa juga diartikan sebagai pengukuran keberhasilan dalam pencapaian tujuantujuan yang telah ditentukan.
Dengan adanya pengertian efektivitas karyawan maka dapat disimpulkan bahwa efektivitas karyawan adalah suatu penyelesaian tugas dengan baik dan benar oleh karyawan sehingga dapat mencapai efisiensi dan efektivitas pekerjaan.

Secara umum dapat dikatakan bahwa komunikasi yang baik dan benar pada karyawan di suatu perusahaan mengindikasikan bahwa terjadi efektivitas kinerja karyawannya.

Suatu komunikasi bahasa yang baik dan benar dibutuhkan juga dalam organisasi dimana dengan adanya komunikasi bahasa yang efektif dapat tercipta suatu efektivitas kerja dalam lingkungan suatu organisasi.

Suatu pekerjaan dapat dikatakan efisien apabila dengan pengorbanan tertentu dapat memberikan hasil yang maksimal di bidang mutu maupun jumlah satuan hasil. Jadi hasil yang maksimal dalam setiap pekerjaan tergantung pada cara kerja yang efisien, berkat usaha berkomunikasi yang efektif yang dilakukan pemimpin perusahaan terhadap para karyawan untuk mencapai hasil yang optimal.

Manajemen yang baik adalah manajeman yang dapat memanfaatkan sumber daya yang tersedia dengan tujuan untuk mencapai dan memelihara tingkat operasional yang efektif. Penyusunan struktur organisasi yang sesuai dengan perkembangan dan kebutuhan perusahaan akan menciptakan kesesuaian kerja, pendelegasian wewenang dan tanggung jawab serta komunikasi yang baik, dapat mempertinggi tingkat efisiensi.

\section{KESIMPULAN}

Komunikasi yang efektif merupakan faktor yang paling berpengaruh dalam kinerja karyawan. Dari komunikasi efektif itu harus dapat menciptakan hubungan yang baik antara manajer dengan karyawan dan di dalam komunikasi tersebut terdapat motivasi, sehingga kinerja 
karyawan dapat meningkat dan pekerjaan di dalam satu perusahaan dapat terselesaikan dengan baik.

Jika manajer dapat menjadi komunikator yang baik, ketegangan yang dirasakan oleh karyawan terhadap atasan dapat berkurang, karyawan pun dapat lebih nyaman dan tidak tertekan dalam mengerjakan pekerjaannya.

Untuk peningkatan kinerja di suatu perusahaan diperlukan komunikasi bahasa yang efektif antara manajer dan karyawan atau antara sesama karyawan baik disampaikan secara lisan maupun tulisan.

\section{DAFTAR PUSTAKA}

A, Chaer Alwasilah. 1985. Sosiologi Bahasa. Bandung: P.T. Angkasa.

Abdillah Hanafi. 1984. Memahami Komunikasi antar Manusia. Surabaya: Usaha Nasional.

Akhmad Subekhi. 2012. Pengantar Manajemen Sumber Daya Manusia. Jakarta: Prestasi Pustakaraya.

Djoko Purwanto. 2003. Komunikasi Bisnis Edisi Kedua. Jakarta: Erlangga.

D. Lawrence Kincaid dan Wilbur Schramm. 1980. Asas-asas Komunikasi antar Manusia. Jakarta: LP3ES.

Gorys keraf. 1984. Komposisi. Ende Flores: Nusa Indah.

Hafied Cangara. 2000. Pengantar Ilmu Komunikasi. Jakarta: Grafindo Persada.

Henry Simamora. 1997. Manajemen Sumber Daya Manusia. Yokyakarta: Liberty.

Jalaluddin Rakhmat. 1985. Sosiologi Komunikasi Massa. Bandung: Remaja Karya.

L.A. Woolcoot, dkk. Komunikasi Bisnis untuk Sekretaris. Jakarta: Erlangga.

Malayu S.P. Hasibuan. 2007. Manajemen Sumber Daya Manusia Edisi Revisi. Jakarta: P.T. Bumi Aksara.
Mansoer Pateda. 1987. Sosiolinguistik. Bandung: Angkasa.

T. Hani Handoko. 2011. Manajemen. Yokyakarta: BPFE.

T. M. Lillico. 1984. Komunikasi Manajemen. Jakarta: Erlangga.

Zein Achmad, dkk. 2012. Membangun Psikologi Kerja dan Aplikasi Etika Profesi. Jakarta: lentera Ilmu Cendikia.

Nasution, F.R., dan Abdul M., (2015). Evaluasi Kinerja Pegawai Dalam Pelayanan Bea Balik Nama Kendaraan Bermotor di Kantor Samsat UPT Pangkalan Brandan, Jurnal Administrasi Publik Universitas Medan Area, 3 (1): 1-7

Mustafa, M.S.,(2015). Kinerja Aparat Kantor Camat Memberikan Pelayanan Administrasi Kepada Masyarakat Di Kecamatan Blangpidie Aceh Barat Daya, Jurnal Administrasi Publik Universitas Medan Area, 3 (1): 4053

Fernanda, A.H., (2015). Pengaruh Kinerja Pegawai Terhadap Efektivitas Organisasi di Biro Umum Bagian Humas dan Protokoler Kantor Gubernur Sumatera Utara, Jurnal Administrasi Publik Universitas Medan Area, 3 (1): 55-67 